\title{
Russian Regions and the Federal Center against Global Threats: A Year of Fighting COVID-191
}

\author{
V. E. Seliverstov ${ }^{a, *}$, N. A. Kravchenko ${ }^{a, b, * *}$, V. I. Klistorin ${ }^{a, b}, * * *$, and A. T. Yusupova ${ }^{a, b, * * * *}$ \\ ${ }^{a}$ Institute of Economics and Industrial Engineering, Siberian Branch, Russian Academy of Sciences, \\ Novosibirsk, 630090 Russia \\ ${ }^{b}$ Novosibirsk National Research State University, Novosibirsk, 630090 Russia \\ *e-mail: sel@ieie.nsc.ru \\ **e-mail: natakravchenko20@mail.ru \\ ***e-mail:klistorin@ieie.nsc.ru \\ ****e-mail: yusupova_a@mail.ru
}

Received December 28, 2020; revised July 21, 2021; accepted July 22, 2021

\begin{abstract}
The article examines the preliminary results and lessons of interaction between the federal center and Russian regions in countering global threats. The specifics of the Russian Federation are revealed that distinguish it from a number of other states in fighting COVID-19, both negative and favorable factors and conditions are considered. It is shown that the Russian Federation, despite how grave the situation was, demonstrated fairly high resistance to unraveling coronavirus crisis during the first wave of COVID-19. In 2020, in federal relations between the center and regions, there were tendencies towards decentralization; however, the redistribution of powers to regions often ran up against the low quality of regional governance. In the context of joint confrontation with global threats, it is shown that in Russia, it is necessary to find a compromise between competitive and cooperative federalism. The pandemic-related growth of the digital economy, expansion of teleworking practices, use of telemedicine, etc., will lead to an increase in digital inequality, asymmetry, and competition among Russian regions. This will require special forms of government regulation and appropriate resources. The article concludes that only a sharp breakthrough in the knowledge economy is capable of ensuring Russia's independence in the future in combating similar global threats (as well as consolidating and strengthening the practice of proactive and effective public administration at all levels: federal, regional and local).
\end{abstract}

Keywords: global threats, pandemic, coronavirus, COVID-19, coronavirus crisis, federative relations, centerregion interaction, combating the coronavirus pandemic in regions, fiscal relations, challenges and threats

DOI: $10.1134 / \mathrm{S} 2079970521040158$

\section{PROBLEM SITUATION}

In 2020, the world faced the global threat of the coronavirus pandemic, which affected almost all aspects of the economy and social life. There had been a truly tectonic shift in the development of the world, and now it is clear to everyone that this world will never be the same as before. This makes it necessary to revise the basic development conditions and principles of countries and their economic and political systems: competition and/or interaction; economic efficiency and/or social justice; independent policy of states and/or their subordination to global laws and a new system of cross-border interactions; the traditional system of organization and labor motivation and/or widespread remote work and networking, etc.

\footnotetext{
${ }^{1}$ The article has been substantially updated and revised by the authors for publication in Regional Research of Russia.
}

The coronavirus pandemic has spread to all countries; its scale and consequences are manifold. The ways in which particular states were prepared to counteract the global threat were governed by their political systems, economic capabilities, effectiveness of the public administration system, level and quality of the health care system, prevailing mentality, and societal culture.

The incidence rates of COVID-19 are different for groups of countries (e.g., in the countries of Northeast Asia and in most countries of the African continent, they were significantly lower than in those of Europe, North and South America, and in India). But it is characteristic that even adjacent states with approximately the same economic scale and development conditions demonstrated different levels of morbidity and mortality from COVID-19. These discrepancies were not only expressed in tens of percent; sometimes the figures differed in multiples. For example, during 
the first wave of COVID-19, the specific incidence rates of COVID-19 per 1000 people in France was 2.1 times higher than in neighboring Germany, and the death rate was 3.1 times higher. Even greater differences were observed between Scandinavian countries. Thus, the specific incidence of COVID-19 in Sweden was 6.3 times higher than in Finland and 4.2 times higher than in Norway; the specific mortality rate was 9.4 and 10.1 times higher, respectively (all data as of mid-December 2020). ${ }^{2}$ There were colossal dissimilarities in development of the coronavirus pandemic in neighboring China and India. All these variances were largely determined not so much by the economic potential and capacities and capabilities of the health care systems of these states, as by state policy adopted in them to counter this global threat.

In each country, the fight against the coronavirus infection relied on four main forces capable of confronting the pandemic: governance at the national and regional levels; science capable of rapidly creating new drugs, vaccines, and remedies against the coronavirus infection; high-tech pharmaceutical business ready to scale up significantly scientific developments; a population and civil society that adequately responded to restrictive measures. The effectiveness and complementarity of these forces varied across countries, due not only to objective reasons (e.g., the level of development of biotechnological and pharmaceutical science), but also to the quality of administrative decisions made at various levels and the crisis management models used.

The global nature of the pandemic is manifested locally; territories within a country show even greater discrepancies in the incidence and consequences of the coronavirus infection spreading. Hence the following question arises naturally: To what extent can the state structure type of individual countries (federal or unitary) and the specifics of center-region interaction determined by this type affect the success of combating global threats? The year of combating the pandemic revealed the best national and regional practices for countering COVID-19.

The objectives of this article are:

- to determine the specifics of the Russian Federation as an object of coronavirus infection spread;

- to analyze, systematize, generalize, and assess the measures to combat coronavirus infection at the federal and regional levels and areas of interaction among various branches of government on these issues;

- to formulate the study's main findings and lessons learned from the first year of combating COVID19 in Russia and its regions.

The main conclusions of the article are presented with respect to the first wave of COVID-19, although several of them take into account the preliminary

\footnotetext{
${ }^{2}$ https://ru.wikipedia.org/wiki/Пандемия_COVID-19.
}

results of the second and the onsetting third waves. The authors did not set the goal to consider in detail the geography of coronavirus infection spread, as well as the related mortality in federal subjects and cities. First, it is a subject of independent research. Second, such a study is possible only after official data on total mortality in Russia and its regions in 2020 becomes available, which will make it possible to speak more reliably about human losses from the pandemic. Finally, there are discrepancies in the methodologies used by various organizations estimating the COVID-19 incidence and mortality. Therefore, all the results should be considered as preliminary. They may be updated as the next waves pass, and a large fraction of the population is vaccinated.

\section{SPECIFICS OF THE CORONAVIRUS PANDEMIC IN RUSSIA}

The topic of various aspects of combating the coronavirus infection deservedly arouses great scientific and public interest. The economic and geographical aspects of development of the COVID-19 pandemic have been the subject of numerous studies (Kuznetsova, 2020; Mau et al., 2020; Nigmatulin et al., 2020; Pandemiya ..., 2020; Shchetinina, 2020; Kalabikhina and Panin, 2020). At the same time, there are hardly any studies on the Russian peculiarities of center-region interaction in the fight against the new global threat.

First, we note the features that significantly distinguished Russia from a number of other federal states at the start of combating the coronavirus pandemic:

- The crisis state of the Russian economy in the prepandemic period. Over the past seven years of stagnation (from 2013 to 2019), per capita GDP increased by only by $3 \%$. As noted by Academician A.G. Aganbegyan (2020a), if we compare 2019 with 2013, when the Russian economy was at the peak of recovery growth, there was a decrease in gross fixed capital formation by $5.5 \%$, expenditures on $\mathrm{R} \& \mathrm{D}$, education, and health care by $6 \%$, exports and imports by $20-$ $25 \%$, disposable household income by $10.4 \%$, and final household consumption by $1.5 \%$. Consumer prices during the stagnation period increased by $55 \%$, which led to increased poverty. Capital outflow from Russia, which has been happening for the 13th year, totaled about USD 800 bln. Statistically confirmed capital outflow from the country for eight months of 2020 exceeded USD $35 \mathrm{bln}$, while for the whole of 2019, this outflow was less than USD 24 bln.

- Western sanctions on Russia introduced in 2014 after Russia's annexation of Crimea. The sanctions were aimed at curtailing contacts and cooperation with Russia in various fields and covered both specific individuals and a few Russian companies.

- The oil shocks of 2020, when oil prices fell more than twofold. According to RosBiznesConsulting, oil 
and gas revenues in the broad sense in 2019 accounted for more than a third of all revenues of the Russian budget system (federal budget, regional budgets, and social funds). Of course, the catastrophic decline in oil prices had a significant impact on the Russian budget.

- The poor quality of public administration at the national and subfederal levels, combined with a high level of corruption.

- Significant polarization of federal subjects by levels of economic and social development (including strong differentiation of federal subjects in terms of the scale and quality of medical services, threefold on average).

- Having one of the longest land borders with China, the country where the virus originated.

Obviously, all this exacerbated the threats associated with the spread of COVID-19 in Russia and its consequences. On the other hand, there were also favorable factors and conditions.

- The large volume of Russia's gold and foreign exchange reserves and the National Welfare Fund accumulated in the previous period. As of October 1, 2020, the National Welfare Fund amounted to USD $125.6 \mathrm{bln}$; international gold and foreign exchange reserves of the Bank of Russia were at USD 583.4 bln (34.3\% of Russia's GDP in 2019, in current prices). At the same time, Russia has a very low domestic debt (less than $15 \%$ of GDP).

- The vastness of the Russian Federation, combined with low population mobility, which created natural barriers to the coronavirus infection spreading.

- The public health system, which had not been completely destroyed since Soviet times.

All this was complemented by the fact that management of the crisis situation in the country in 2020 was directly and indirectly influenced by the political specifics of modern Russia.

- An overly centralized system of state power dominated by the presidential branch. The presidential power vertical was supported by plenipotentiaries of the President of the Russian Federation and their staff in the eight federal districts created in 2002.

- Weakness of political competition and dominance of the ruling party (United Russia) in the legislative and executive bodies at the national and subfederal levels. Out of 85 governors, only seven represent the parties of the systemic opposition, two were elected as independent candidates, and 20 were formally nonpartisan but actually nominated or supported by the ruling party. That is, United Russia, as the ruling party, had secured influence over $90 \%$ of Russian governors.

- The voting planned for mid-2020 on amendments to the Constitution (including on the renewed conditions for the President's term in office).

From their impact on the COVID-19 pandemic, the noted features of the Russian Federation acted in different directions. For the purposes of further analysis, we only state that Russia, as an object of the spread of a new global threat, is an asymmetric federation with an extremely centralized system of public administration with low quality. In these conditions, serious risks of explosive and uncontrolled development of the coronavirus pandemic in the country were expected. Fortunately, these expectations did not come true. As our analysis and research by other authors have shown, the Russian Federation, despite how grave the situation was, demonstrated fairly high resistance to unraveling coronavirus crisis during the first wave of COVID-19.

An important specific feature of Russia was that the pandemic arrived in Russia one to two months later than in many other countries. This happened because the authorities quickly closed the border with China (from January 31, 2020) and later with other countries. This allowed Russia to gain time and create the minimum necessary conditions for admitting patients both in Moscow and in regions.

Another important feature of Russia's confrontation with COVID-19 was that the country relied heavily on its own scientific developments and high-tech companies. Thus, Russia has become one of the world leaders in the number of coronavirus tests performed (about 83 million as of mid-December 2020). In midAugust 2020, the world's first two-component vector vaccines against COVID-19 (Sputnik-V) were registered under an accelerated scheme. After that, the third massive stage of clinical trials began, and in December, vulnerable groups (doctors, teachers, etc.) started to get them vaccinated. It was assumed that by the end of 2020, about $2 \mathrm{mln}$ packages of this vaccine would have been produced. The second vaccine (EpiVacCorona), developed by the Novosibirsk State Scientific Center of Virology and Biotechnology Vector, was registered on October 14, 2020, and in December of that year, vaccination began in various regions (but in smaller volumes than Sputnik-V). On February 20, 2021, the third vaccine, KoviVac, was registered (developed by the Chumakov Federal Scientific Center for Research and Development of Immunobiological Preparations); vaccination began in spring 2021. On March 29, 2021, the fourth Russian vaccine, Sputnik Light, was registered, which is now also actively used for mass vaccinations. These vaccines are based on different principles and biomedical technologies.

Let us now note some regional features in the development of the coronavirus pandemic in the Russian Federation.

(1) In Russian regions, the epidemic began on average two to three weeks later than in Moscow. It was the incidence in the capital in the first two months that largely determined the overall pattern of the coronavirus infection in Russia. Significant financial and material resources allocated for the fight against the disease in Moscow by metropolitan and federal authorities, the higher level of development of medi- 
cine here (including high-tech), as well as the effective activity of the metropolitan government in fighting the pandemic made it possible to steer COVID-19 situation in a manageable direction. This initial period was used by the other regions in emergency preparation for the expected surge in the number of COVID-19 cases. Starting from the last decade of May 2020, the number of cases in the rest of Russia exceeded the Moscow figures, and already other regions began to determine the development dynamics of COVID-19 in Russia.

(2) There is a strong differentiation between federal subjects in the incidence of COVID-19 (Pandemiya ..., 2020; Zubarevich, 2020). On the one hand, regions with a high concentration and intensive movement of population, including the largest cities, regions of the North Caucasus and northern regions with predominant rotational work, have been most affected by the coronavirus pandemic. On the other hand, the sectoral specifics of regions and cities influenced the incidence rate: e.g., territories with a high concentration of the service sector turned out to be the most vulnerable.

(3) When analyzing data on the territorial characteristics of the incidence of COVID-19, it should be borne in mind that these indicators directly correlate with the capacity of test laboratories in the regions. In their absence, a lower incidence of COVID-19 in certain territories will be objectively recorded. Therefore, we repeat, a reasonable analysis of the spatial specifics of the spread and consequences of the COVID-19 pandemic can be done only when information has been received on the excess total mortality in regions in 2020 compared to previous years (clearly, it will be necessary to isolate the impact of the COVID-19 on this dynamics).

These are the initial conditions, the general background for assessing the ability to manage the coronavirus pandemic in Russia at the national and regional levels. Let us consider these processes in more detail.

\section{DEPLOYMENT OF MEASURES TO COMBAT THE CORONAVIRUS PANDEMIC IN RUSSIA}

The unprecedented crisis associated with the spread of the COVID-19 pandemic caused changes in organizing the activity of state authorities and administration in Russia, primarily in the relationships and functions of various levels of the federal structure: central, regional, and local.

The country's crisis management related to the spread of the coronavirus pandemic relied on the regulatory framework established earlier. It was, in particular, reflected in Federal Law no. 68-FZ of December 21, 1994, On Protection of the Population and Territories from Natural and Man-Made Emergencies, which described, among other things, the introduction of a state of emergency and emergency situations. In 2011, an amendment to this law fixed the possibility of introducing a high alert regime in the regions.

Although federalism in Russia has been characterized by a tendency towards centralization since the early 2000s (Leksin, 2008; Seliverstov, 2015), the pandemic crisis has to some extent changed the power distribution between the center and regions. By Decree of the President of the Russian Federation no. 239, the development and implementation of a set of restrictive and other measures aimed at combating the coronavirus infection and ensuring public health, as well as supporting economic activity, starting from April 2020, were entrusted to senior officials of Russian regions under their personal responsibility. Despite how proper this decision was, it created serious economic problems in federal subjects. Measures to combat the epidemic and support the affected population groups and businesses were taken not so much basing on assessed problems severity but on available resources. Of course, although the federal government allocated additional resources to regions for these purposes, a significant part of the costs came from regional budgets.

At the same time, President of the Russian Federation V.V. Putin retained tight control over the activities of the regional authorities for himself and state government. This included the plenipotentiary representatives of the President of the Russian Federation in eight federal districts and their staffs. When transferring powers to manage the COVID-19 situation to federal subjects, the federal government exercised certain leadership over these actions, e.g., based on the development of model recommendations for regional leaders, criteria for easing restrictive measures, etc.

At the stages of deploying measures to combat the COVID-19 pandemic, the role and importance of a number of federal structures changed. Thus, the Federal Service for Supervision of Consumer Rights Protection and Human Welfare (Rospotrebnadzor) and its departments for federal subjects came to the fore. It was here that all operational information on the spread of the pandemic was concentrated and analyzed, and decisions and recommendations were prepared for other federal executive bodies.

The Russian Defense Ministry significantly contributed to combating COVID-19. In the shortest possible time (on average, within two months) in various Russian regions, 30 inpatient COVID-19 hospitals were built, replete with modern equipment and staffs of specialists. In some particularly disadvantaged federal subjects (Republic of Dagestan, Zabaykalsky Krai, etc.), military field hospitals were deployed to combat COVID-19, military structures carried out sanitization of a number of the most infected areas.

In the entire complex and internally interconnected system of measures to manage the situation with the COVID-19 pandemic in the country as a whole and in its regions, the role of the Russian presi- 
dent should be noted. V.V. Putin, especially in the early stages, took the lead in managing the situation and in constant communication with federal and regional authorities. In April-May 2020, in the format of videoconference, he held almost weekly meetings with the governors, which were broadcast on television.

It is significant that in Russia, unlike other countries, the fight against the coronavirus pandemic was not associated with an inter-party struggle. The entire systemic opposition fully supported the President of the Russian Federation and the Russian government in the measures they were taking. The nonsystemic opposition also did not consider it expedient to play on the pandemic difficulties. All this was consolidated in the process of combating the pandemic with strict discipline in the ruling party (United Russia), to which most of the governors' corps belong.

\section{ACTIONS OF THE FEDERAL CENTER}

In addition to restrictive measures preventing coronavirus infection spread into Russia, including closing the borders with China and later with other countries, suspension of most flights, rail links, etc., the actions of the federal government in fighting the coronavirus pandemic and its consequences boiled down to three the main directions: monitoring the situation and creating awareness among the citizens; management and coordination of activity; planning and developing general principles of restrictive measures, support tools, reducing restrictions and financing the proposed measures.

Monitoring and Creating Awareness. In conditions of uncontrollable uncertainty, a "panic epidemic" is much worse than a viral one. The growing flow of spontaneous and unverified information about development of the disease and its spread (in particular, in self-isolation conditions) contributes to increased tension and frustration in society. Therefore, at the federal level in Russia, fines for fake reports about the spread of COVID-19 were quickly introduced (although they were not applied en masse). In midMarch 2020, the State Centre for Information of Citizens about the Coronavirus was organized and created an official Internet resource for the population (https://stopcoronavirus.rf). It provides real-time data on the situation in Russia and in all federal subjects (numbers of infected, recovered, and deceased), support measures at the federal and regional levels, and other operational information. In addition to government sources, many others are available. ${ }^{3}$

\footnotetext{
${ }^{3}$ For example, Russia's largest Internet company, Yandex, provides rapid information not only based on primary data, but also various indices created using digital technologies, including the self-isolation index for cities in Russia and major world cities (https://yandex.ru/covid19).
}

Management and Coordination. From April 2 to May 30, 2020, the President of the Russian Federation issued three decrees (nos. 239, 294, and 316), granting the top officials of federal subjects expanded powers to take measures aimed at ensuring the sanitary and epidemiological well-being of the population in the corresponding federal subject in connection with the spread of the new coronavirus infection.

At the federal level, several structures that are obliged to develop and implement measures to combat the coronavirus infection and support the economy, as well as coordinate the activities of many departments and services at the federal and regional levels were created. On January 27, 2020, the Operational Headquarters for Interaction Between Relevant Executive Authorities was created to develop measures to prevent the importation of the new coronavirus infection into the territory of the Russian Federation and its spread. On March 5, 2020, the Government Commission to Ensure Sustainable Economic Development was formed. On March 14, 2020, the Coordination Council for Combating the Coronavirus was created. On March 15, 2020, by order of the President of the Russian Federation, the State Council Working Group to Counter the Spread of the Novel Coronavirus Infection was convened, focused on interaction with the heads of the federal subjects.

Administration and coordination affected the system for lifting restrictions associated with the first wave of COVID-19. May 11, 2020, marked the end of "non-working days" lasting across the country since 28 March. The federal government announced a three-step plan to ease restrictions, giving governors the power to decide when and how, but with strict compliance with federal health regulations. ${ }^{4}$

Planning and Support. The most important results of the work of the above-mentioned government commission and coordinating bodies should be considered the development of the Plan of priority measures (actions) to ensure sustainable economic development in conditions of a worsening situation due to the spread of the novel coronavirus infection (approved by the Government of the Russian Federation on March 17, 2020), followed by the Plan to overcome the economic consequences of the novel coronavirus infection (approved April 20, 2020).

Throughout April and May 2020, the government announced three packages of measures to combat the pandemic and support the economy and population.

The first included credit holidays for small and medium-sized businesses and citizens, financial sup-

\footnotetext{
${ }^{4}$ At the first stage of reopening, people could walk and play sports in the fresh air; small shops and service establishments could start working again. At the second stage, schools, large stores, and service enterprises were opened. At the third stage, parks, hotels, restaurants, and all shops were opened. Criteria for lifting restrictions in certain regions included the infection rate, availability of hospital beds, and testing capabilities.
} 
port to affected industries, and a preferential loan program to offset lost wages. The most significant measure was the reduction in the rates of social insurance payments from 30 to $15 \%$ for small and medium-sized businesses. The total volume of the package was estimated at $0.3-0.4 \%$ of GDP. Less than $10 \%$ of entrepreneurs managed to receive support from both the budget and banking system, which influenced the government's decision to submit a second package quickly. It included support for backbone enterprises, support for regional budgets, and additional payments to medical workers. Taking into account the state guarantees provided, the size of the second package amounted to approximately $1 \%$ of GDP.

Both packages drew criticism due to their modest size, their focus on supporting businesses rather than citizens, and the lack of direct payments to the public. The third support package was larger, RUB $\sim 800-$ $900 \mathrm{bln}$, and its main feature was the inclusion of direct payments to the residents: families with children, people who lost their jobs as a result of business lockdowns, and other socially vulnerable groups.

The plan to overcome the economic consequences of the new coronavirus infection determined the position of the federal government on the directions and forms of support for the economy and people. This plan is regularly updated, but its main directions have remained unchanged: mainly, the support measures have been prolonged. Due to the growth in the number of enterprises and citizens who have lost their sources of income as a result of the crisis, ${ }^{5}$ decisions to increase the amount of support were made. According to Finance Minister A.G. Siluanov, the level of support for the economy in 2020-2021 should amount to $\sim 9 \%$ of GDP. ${ }^{6}$

Federal aid includes support for: (1) healthcare organizations, including the purchase of medical equipment and medicines and construction of hospitals; (2) medical and pharmaceutical industries; (3) small businesses in the most affected industries, as well as backbone enterprises; (4) people (families with children, unemployed, self-employed); (5) regional budgets; etc. The forms of support are aimed at making it easier for companies to access loans and guarantees, reduce business expenses (taxes, payments on loans and borrowings, insurance payments, rent, etc.), reduce the administrative burden and unproductive business expenses, ease the financial burden for borrowers, as well as for direct payments to workers in affected industries and to families with children.

\footnotetext{
${ }^{5}$ According to the plan, in April 2020, the crisis associated with the coronavirus pandemic in Russia affected $5.3 \mathrm{mln}$ people, of which $3.3 \mathrm{mln}$ worked in small and medium-sized businesses. In October 2020, already $6.7 \mathrm{mln}$ people were affected, of which $5.3 \mathrm{mln}$ worked in small and medium-sized businesses.

${ }^{6}$ See TASS News Agency interview with A.G. Siluanov, October 25, 2020 (https://tass.ru/ekonomika/9816805).
}

It should be noted that a number of federal support measures in practice turned out to be less effective. Support for small and medium-sized businesses affected by the pandemic was often stipulated by conditions that actually excluded a significant number of enterprises from it. In certain cases, some of these restrictions were later removed.

On September 23, 2020, the Government of the Russian Federation approved the National Plan of Action to Ensure Restoration of Employment, People's Incomes, Economic Growth, and Long-Term Structural Changes. It was aimed at restoring employment and effective demand, supporting entrepreneurship, launching a new investment cycle, and improving the business climate, as well as accelerating the technological development of the economy, increasing exports and supporting import substitution. The plan was designed for the period until the end of 2021 and is divided into three stages: adaptation, recovery and active growth of the economy and household income. In accordance with this plan, by the end of 2021, GDP growth will be at least $3 \%$ per year and the unemployment rate should be below 5\%. The cost of 500 specific measures of the plan exceeds RUB 6.4 trln, but more than 4 trln have already been spent (the plan combines both the already implemented anticrisis packages of April-June 2020 and new development goals until 2021). At the same time, the Unified Plan to Achieve National Goals up to 2030 is already underway.

An important field of activity of the federal center in fighting COVID-19 in the first months was to increase the amount of protective equipment, equipment, and medicines. As a result, e.g., whereas at the beginning of 2020 domestic industry produced $60-$ 70 mechanical ventilation devices per month; in April, this was more than 800, and more than 2500 in May. Production of protective masks during the pandemic increased by more than 20 times. In fact, mass production of a number of drugs in demand for treating COVID-19 was launched from point zero.

In March-April 2020 alone, the production of Russian test systems for detecting COVID-19 increased by nine times. As of mid-October, 200 test systems were used in the country for diagnosing coronavirus and antibodies, including more than 80 domestically developed systems. As a result, during this period, Russia took a place among world leaders in the absolute indicators for coronavirus tests (fourth after the United States, India, and China).

Whereas before the pandemic began, there were 52000 adult and pediatric hospital beds in Russia, by mid-October 2020, there were almost 200000 units, a fourfold increase.

Thus, the overall direction of the federal government's actions in fighting the coronavirus pandemic, as well as prompt proactive decision-making, should be assessed as positive. However, many experts (Aganbegyan, 2020b) agree that the amount of allocated 
resources could have been significantly larger. The accumulated gold and foreign exchange reserves of the country and the existing National Welfare Fund would have made it possible. IMF estimates also show that Russia is an outsider among the G20 countries in the specific volume of financial support related to the pandemic. $^{7}$

Nevertheless, we believe that the actions of the federal center as a whole were adequate to the conditions of the crisis; the reaction of the authorities to emerging problems and changing conditions in some cases was delayed or support was carried out on a smaller scale, but efforts to solve problems were made in the right direction.

\section{ACTIONS OF FEDERAL SUBJECTS}

Decentralized decision-making in a crisis is caused by the need to take into account the strong differentiation between Russian regions, both in the level of socioeconomic development and provision of material and nonmaterial resources. As experts point out (Smyth et al., 2020), this situation often arises in unmanageable crises such as COVID-19, when the center tries to shift the costs and responsibility for the use of harsh or unpopular measures to regional authorities.

As noted above, the task of finding compromises between the need to preserve public health, measures to combat COVID-19 and support economic activity at a certain stage of development of the situation was transferred to the governments of Russian regions. It was the governors, not the president, who began to make decisions on locking down companies and limiting the mobility of people.

The regions actively participated in fighting the pandemic, and in March 2020 alone, the heads of regions issued more than 1000 regulatory acts containing requirements on restrictions with varying degrees of severity. The speed of the regional governments' reaction largely depended not on the peculiarities of the local epidemiological situation, but on statements by the central government. In Russia, in contrast to many other countries, a state of emergency was not declared at the national level as a whole. Most regions (45 federal subjects) introduced a high alert regime, while the rest introduced different versions of the restriction regime, quickly responding to outbreaks. ${ }^{8}$

Experts of the Petersburg Policy Foundation 9 divided the federal subjects into three groups according to the severity of restrictions (viral sovereignty

\footnotetext{
${ }^{7}$ IMF. 2020. Policy-Responses to COVID-19. Russian Federation. https://www.imf.Org/en/Topics/imf-and-covid19/PolicyResponses-to-COVID-19\#.

${ }^{8} \mathrm{http}$ ://base.garant.ru/77398959/.

${ }^{9}$ Rating of the Petersburg Politics Foundation for August 2020. https://davydov.in/politics/rejting-fonda-peterburgskaya-politika-za-avgust-2020-goda/.
}

index). The most severe restrictions were adopted in 14 regions; 33 federal subjects were attributed to regions with an average level of severity, and 36 federal subjects introduced relatively soft restrictions.

The toughest measures were taken in Moscow, including the use of digital QR codes to control the movement of citizens. Some other federal subjects also introduced digital passes, but later abandoned this practice. In a number of regions, control was introduced over visitors from Moscow, St. Petersburg, and other large cities. Many regions tried to impose strict control over roads (e.g., Nizhny Novgorod); the Chechen Republic and Republic of Crimea first completely restricted entry to their territory, but then somewhat weakened these restrictions. ${ }^{10}$

On May 12, 2020, Russia ceased the regime of nonworking days with preservation of wages announced by President Putin at the end of March. However, it was left to the heads of the regions that introduced them to decide when to start lifting specific restrictions. Since May 2020, Russian regions began to weaken quarantine restrictions, which happened almost immediately after the number of cases peaked. In Moscow, most restrictions were significantly eased or lifted as early as June, but in other regions, the restrictions persisted longer and decreased significantly by the beginning of the school year.

The measures taken by regional governments to combat the pandemic have led not only to a gradual decrease in the number of cases, but also to a sharp contraction in demand and a drop in people's incomes, curtailment of a significant part of the service sector, and almost complete reduction in the activity of a number of industries (passenger transportation, tourism, hotel and restaurant; etc.). The most destructive government restrictive measures had been placed on service sector and small and medium-sized businesses.

The abovementioned action plan for overcoming the COVID-19 adopted by the central government built a support system for industries, people, and regions. All 85 federal subjects introduced economic measures to support business on their territories: 84 regions introduced non-tax-related measures (reduction in rental rates, subsidies, etc.); 80 also introduced tax-related measures (rate reductions, deferrals, etc.). In total, it is estimated that 839 economic measures were used in regions (45\% taxrelated, 55\% non-tax-related). The most commonly applied have been tax breaks, rent deferrals for small businesses and companies from affected industries, and subsidies for small and medium-sized businesses.

\footnotetext{
${ }^{10}$ The actions of the head of the Chechen Republic R.A. Kadyrov on the region's borders complete closure met with criticism from the Prime Minister of the Russian Federation M.V. Mishustin, who warned the Chechen leader about the inadmissibility of confusing regional powers with federal ones.
} 
According to the National Rating Agency, ${ }^{11}$ the largest package of measures to support businesses affected by the pandemic was adopted by Moscow; the republics of Buryatia and Crimea; Perm Krai; the Chukotka Autonomous Okrug; and Tula, Irkutsk, and Chelyabinsk oblasts. Support from local authorities is able to reduce the decline in regional economies, but currently, it has been negatively affecting many regional budgets. Restrictive measures combined with regional characteristics, not the spread of COVID-19 itself, have had a negative impact on regional economies.

Thus, in these regions, the search for a balance between economic well-being and the health of residents was quite expectedly shifted towards economic well-being. A certain confirmation of this can be the amount of gratuitous assistance to the mentioned regions at the expense of the federal budget. ${ }^{12}$ Of course, the question of the relationship between the designated support measures and their effectiveness remains open. As survey data have shown (including a survey conducted by the authors in May 2020), support measures were not available to everyone in need.

In an interview given to the authors of this article, the governor of Novosibirsk Oblast, A.A. Travnikov, noted: "From the standpoint of Russian federalism, this year we managed to ensure a good balance and compromise between centralization and the independence of federal subjects. We have been moving towards this systematically for the last three or four years, and now the relationship between the federal center and regions is changing dramatically, including in the field of interbudgetary relations. For the third year in a row, we are entering a new budget cycle, knowing in advance the volume of transfers from the federal budget by $90 \%$; we could not have even dreamed of this before. New platforms for centerregion dialog began to actively develop, the most wellknown of them being the State Council. With regard to combating the coronavirus pandemic, we were guided by certain recommendations and 'templates' passed down from above; on the other hand, we made our own administrative decisions."

However, there are also more radical opinions about changes in the system of regional government in Russia under the influence of the coronavirus crisis, reflecting the asymmetry of the center-region relations: "This is a no-obligation vertical that works mostly in one direction-it takes a lot, but gives little in return" (Pertsev, 2020). Experts (Komin and Poltoratskaya, 2020; Trunova and Zemlyanskii, 2020) emphasize that the consequences of the transfer of

\footnotetext{
${ }^{11}$ Between Scylla and Charybdis: how Russian regions are coping with the economic consequences of the pandemic. https://www.investinregions.ru/analytics/a/materials-71332/.

${ }^{12}$ Rating of the Petersburg Policy Foundation for August 2020. https://davydov.in/politics/rejting-fonda-peterburgskaya-politika-za-avgust-2020-goda/.
}

authority and responsibility for combating COVID-19 to the regional level in conditions of insufficient resources will primarily be manifested as an increase in regional expenditures (according to estimates, budget expenditures increased by $30 \%$, and more than half of regions are experiencing increased budget deficits), which in turn will strengthen the dependence of most regions lacking their own sufficient resources on the center and its financial support. The possibilities of supporting the population and business in regions depend on the level of development of their economies and social spheres (primarily, the health care system). Consequently, more developed and richer regions will be able to cope more effectively with the pandemic than poorer regions, which will further increase regional differentiation. Possible long-term negative consequences include the pending problems in the economy (including as a result of reduction in private sector investment government spending on $R \& D$ ) and increased social tensions.

The most decisive and innovative measures during the first wave of the coronavirus pandemic were adopted in Moscow. A video surveillance and face recognition system (according to experts, one of the strongest in the world) was used to control the movement of COVID-19 patients, special regimes (according to the schedule) for Moscow residents to go out for walks and groceries during the height of the first wave, a QR code system, systems for controlling the movement of personal vehicles, etc. City authorities paid much attention to the development of the remote learning system for schoolchildren and students. We believe that it was the coronavirus crisis management system implemented in Moscow that determined to a significant extent the general trends in fighting COVID-19 in Russia, when in general it was possible to avoid economic collapse and social outrage associated with the pandemic.

However, it should be borne in mind that Moscow is an atypical Russian city. On the one hand, it is the largest metropolis in Europe $(12.7 \mathrm{mln}$ people) with a huge budget and a healthcare system that is more developed than anywhere else in Russia. On the other hand, it is the capital of Russia, which has federal subject status and special forms of interaction with the central government. Nevertheless, Moscow's experience in combating global threats (e.g., COVID-19) can be further applied by the authorities of other large Russian cities. Moscow can become a kind of a laboratory of administrative decisions, inscribed in the concept of a digital economy and a smart city.

However, horizontal cooperation between regional authorities in fighting COVID-19, in general, did not enjoy intensive development, since each government was responsible for taking preventive measures and current counterepidemic measures only on its own territory (of course, activity was coordinated and information exchanged between them, as earlier). The 
offices of the plenipotentiary representatives of the President of the Russian Federation in eight federal districts made a certain contribution to horizontal cooperation on issues of joint opposition to the COVID-19 threat in federal subjects. However, control of these processes still dominated over organizational and mobilization functions.

During the pandemic, many problematic issues in the interaction between the federal center and regions were resolved through hands-on management (very habitual in Russia). A number of governors sought a personal meeting with the President of the Russian Federation, during which they asked for special forms of federal support in connection with the crisis situation in their regions. Such informal agreements led to, e.g., the creation of Russian Defense Ministry field hospitals for coronavirus patients in Dagestan and other regions, as well as stationary hospitals in federal subjects, etc.

In general, decentralized decision-making on measures to combat COVID-19 has played an important role in curbing coronavirus infection spread across Russia, but how sustainable this containment was remains unknown. Regions used various combinations of restrictive and support measures, but it is too early to assess the effectiveness of such decisions in regional policy.

\section{INTERBUDGETARY RELATIONS}

The modern model of budgetary federalism in Russia took shape in the early 2000 s and is distinguished by a high degree of centralized budgetary resources. The share of revenues of regional and local budgets in the consolidated budget of the Russian Federation is $34.7 \%$, including own revenues $(32.1 \%)$ and transfers $(2.6 \%)$. However, in some regions, the share of transfers in revenues exceeds $70 \%$, e.g., in the republics of the North Caucasus and the Republic of Crimea.

In the context of the pandemic and decline in world prices for most export goods, regional and local budgets faced a reduction in their own revenues. However, increased transfers from the federal budget made it possible to reverse this situation for most federal subjects. In the first half of 2020, the volume of interbudgetary transfers provided to regions amounted to RUB 1.4 trln and increased by 1.6 times versus same period in 2019. At the same time, resources between various financial support were reallocated.

In general, the revenues of the consolidated budgets of federal subjects in January-June 2020 increased by $2.1 \%$ versus the corresponding period of 2019, amounting to RUB 6.3 trln, while expenses increased by $18.9 \%$, amounting to RUB 6.5 trln. This ratio of income-expense growth rates is explained by the fact that in the first half of 2019, the total surplus of regional budgets was RUB 695.7 bln, while in 2020, a RUB 213.7 bln deficit was created. The increase in expenditures was mainly covered by gratuitous receipts from the federal budget. After the transfer, a decrease in the revenue side of the consolidated budgets of federal subjects was observed in 16 regions, of which the largest was in the Yamalo-Nenets Autonomous Okrug (by 19.2\%) and Tyumen Oblast (by 17.2\%). An increase in revenues was observed in 69 federal subjects, of which the largest was the Jewish Autonomous Oblast (by 39.3\%) and the Republic of Ingushetia (by $35.2 \%) .{ }^{13}$

Of course, the economies and budgets of most regions (with few exceptions) have suffered from pandemic-related restrictions, industrial output has decreased, unemployment has increased, and budget deficits have increased.

Support for the regions in which revenues had fallen was in the form of transfers and grants, as well as restructuring of bank loans. In addition, the measures of liability for nonfulfillment of obligations under agreement with regions and requirements on the debt burden for commercial loans were relaxed. An amount of RUB 1.4 trln was allocated to regions from the Reserve Fund of the Russian Federation, which were mainly used to finance measures to alleviate the deteriorating situation in economic sectors, as well as to prevent coronavirus infection spreading and elimination of its consequences.

The revenues of regional budgets that decreased from restrictions on economic activity are estimated at about three times higher, so support from the center is certainly necessary, but so far, the amount has been insufficient.

In the system of interbudgetary relations, significant resources were allocated to overcome negative processes. For this, the federal and regional budgets were promptly adjusted. However, budget allocations have been extremely uneven and incomplete. In 2020, the budgets of the richest oil and gas regions suffered the most, but this was unassociated with interbudgetary relations.

\section{IMPACT ON ADMINISTRATIVE POLICIES OF THE CENTER AND REGIONS}

Summing up the analysis of the development of the coronavirus pandemic in Russia and the joint fight of the center and regions against this global threat, we note again that, in accordance with the country's leadership, governors, and experts, the situation with COVID-19 during the first and second waves was difficult and very tense, but not critical. During this period, the country managed to avoid the explosive development of the pandemic, as well as economic,

\footnotetext{
${ }^{13}$ Operational report on execution of the federal budget and budgets of state extrabudgetary funds: January-June 2020. https://ach.gov.ru/upload/iblock/635/6355465c8c52f3ed915cc 39757263157.pdf
} 
social, and epidemiological collapse. At the same time, the Kremlin recorded the maximum load on the domestic health care system due to coronavirus infection spreading, when a critical line in fighting infection had already been reached in several regions, when more than $90 \%$ of beds for those infected with coronavirus were occupied. ${ }^{14}$ The first data on excess mortality in Russia in 2020, published in early 2021, forced a revision of previous optimistic statements that the COVID-19 mortality rate in the Russian Federation was significantly lower than in other developed countries.

The situation worsened with the beginning of the third wave of COVID-19, which was largely associated with a new, more pathogenic, and dangerous delta strain of the coronavirus infection spreading deeper into the country. It began to affect the youth, and the rate of its spread increased significantly, along with the mortality rate. In a number of regions and cities, the situation began to exceed the critical level (e.g., in St. Petersburg), largely due to shortages in regional health systems (primarily, medical and service personnel). ${ }^{15}$ It became clear that extraordinary measures were needed to accelerate vaccination, the pace and scale of which were clearly insufficient, and this became, perhaps, the main area of interaction between the federal center and regions in countering the coronavirus pandemic.

Therefore, the aggressive development of the third wave of COVID-19 in Russia has corrected the strategy and tactics of combating COVID-19 and administrative policies of the federal and regional governments. As before, in order to avoid a national lockdown in every possible way, the Kremlin issued a serious carte blanche to regions for the introduction of more stringent restrictive measures (including local lockdowns), and a number of regions (e.g., the Republic of Buryatia) were forced to use them. However, the main measures, as noted above, were aimed at significantly accelerating the vaccination rates among the Russian population.

As in any country, the level of vaccination in Russia is determined by the three factors: the presence of domestic capacities for the production of vaccines and/or scale of their import; the people's readiness to be vaccinated voluntarily; the organization of the vaccination process at the federal, regional, and local levels plus the interaction of the relevant authorities on these issues. Here we should note three features of this process with respect to the situation in Russia:

\footnotetext{
${ }^{14}$ Peskov, D., A number of regions have reached a critical point in fight against coronavirus, TASS, 2020. https://tass.ru/politika/9848607. Accessed November 15, 2020.

${ }^{15}$ In general, the situation with COVID-19 in Russia's second capital, St. Petersburg, which also has federal subject status, significantly differs from that in Moscow. Despite lower specific morbidity indicators (about 20\% lower), the specific mortality rates from COVID-19 in St. Petersburg are more than $80 \%$ higher than in Moscow.
}

-Scaling up production of domestic vaccines has not yet reached the required level; Russian companies will reach it only in July-August 2021. As well, Russians currently do not know which of the domestically produced vaccines are in use in Russia, and which are being sent to other countries (although there were earlier official statements that all vaccines produced in the country are being used exclusively to vaccinate the Russian population, and the domestic vaccine supplied to other countries is being produced at new facilities in Turkey and other countries, where its production technology has been transferred).

- In Russia there is a large public stratum (according to experts, about a third) that does not want to be vaccinated either for fundamental reasons, or due to disbelief in domestic developments and the safety and effectiveness of Russian vaccines. In the latter case, this is a problem of a deeper nature: the citizens' distrust of the state and regional authorities. And here it seems that the upper echelon's persistent statements to Russian citizens that Sputnik-V is the most effective and safest vaccine in the word have backfired, especially since the World Health Organization has not officially recognized the Russian vaccine.

- In avoiding unpopular measures at the federal level associated with all-Russian compulsory mass vaccination (particularly, on the eve of the autumn elections to the State Duma, the lower house of the Russian parliament), the center began to shift responsibility to the authorities of Russian regions, giving them the right to introduce compulsory vaccination for special categories citizens, and it seems that this process began to accelerate considerably. ${ }^{16}$ At the same time, the Russian authorities often implicitly blame the country's insufficient vaccination rates on the people evading vaccinations, when in many cases it is due to a shortage of vaccines and supply failures in regions.

Therefore, acknowledging the seriousness of the third wave and the particular importance of overcoming it by vaccinating a large share of the population, recently, the president and state government have ramped up their participation both insolving the problems of upscaling the production and regular regional delivery of Russian vaccines and dialoguing with governors, urging them to pay particular attention to working with the people, earnestly and reasonably urging them to get vaccinated as soon as possible.

As for the economic consequences of COVID-19, in the context of the second wave of COVID-19, the federal and regional authorities focused on maintaining economic activity and did not consider the possibility of introducing new widespread restrictive mea-

\footnotetext{
${ }^{16}$ Against the background of disputes about the need for compulsory or voluntary vaccination in Russia, you assess the situation in China, where more than 1 bln doses of vaccine have been administered to the population, where "COVID dissidence" and refusal to vaccinate are unthinkable.
} 
sures. No lockdown was introduced at the national or regional level. One of the arguments against new quarantine restrictions and closing of borders between regions during this period was expansion of the healthcare system, implementation of mass testing of domestic vaccines against COVID-19, and from December 2020, the beginning of mass vaccination. During the peak of the third wave, it seemed that a lockdown was inevitable in many regions, but this was avoided.

International experts (Hale et al., 2020) also had some optimism in assessing the current situation in Russia. They considered that although cases in the country were increasing, the risks to the national economy were at anacceptable level for easing restrictions in accordance with WHO recommendations. It was estimated that Russia was in the group of countries with a below average risk of reopening the economy and a moderate stringency of restrictions. It was assumed that, on the whole, by the end of 2020, the expected drop in Russia's GDP would be about $4 \%$, but the second wave of the coronavirus crisis could have led to more than $5 \%$ economic recession, while in the next three years, a growth rate of no more than $2.5 \%$ was predicted.

However, the real drop in Russian GDP in 2020 turned out to be lower (3.1\%). This was facilitated not only by the trend of recovery growth and rise in oil prices, but also by the absence of lockdowns and more loyal attitude of the federal and regional authorities to economic restrictions in a number of industries and services.

In general, we believe that since the period of the decrease in the first wave, both federal and regional authorities "relaxed" and began to pursue an insufficiently stringent policy in fighting this global threat. This manifested itself in the reopening of Russian resorts during the summers of 2020 and 2021, international airlines to resorts in other countries, concessions to pressure from governors of the southern resort regions and restaurant and hotel lobbyists demanding pandemic restrictions to be lifted, etc. As a rule, the negative results of such loyalty were not long in coming.

The origins of the problems of effective centerregion interaction in Russia in countering global threats (economic crises, etc.) lie in the past, but the current situation has made their solution even more urgent. During the coronavirus pandemic, the need for rapid solutions and a high level of diversity in living conditions and activity in individual federal subjects inevitably led to delegation of decision-making to the regional level for specific measures to combat the coronavirus. This process exacerbated existing problems and created new ones. In particular, we note four of them.

(1) One of the main problems of Russian federalism is the contradiction between the scope of respon- sibility of regional (and municipal) authorities and administration, the available resources at their disposal, and powers they are endowed with. Insufficient, according to the center, activity by the heads of regions in fighting the pandemic led to several resignations of governors (Kamchatka Krai, Arkhangelsk Oblast, and the Komi Republic). However, in general, the President of the Russian Federation and central government very rarely intervened in the actions of regional authorities.

(2) The multiplicity of channels for transmitting information requiring response and the complexity of coordinating separate departments led to situations where only direct intervention by the President of the Russian Federation could solve the problem. In a number of regions, a paradoxical situation has developed with payments to medical workers treating coronavirus patients. In accordance with the President's order, they were to receive significant additional payments. However, in some regions, payments were calculated taking into account the direct time spent in contact with patients, which caused numerous complaints from doctors. The system changed after President Putin demanded that local leaders stop their bureaucratic gimmicks.

(3) Problems have intensified with a number of national autonomies significantly inferior to other Russian regions in socioeconomic development (national republics of the North Caucasus, republics and autonomies of Siberia and the Far East). Due to their relative isolation and low population mobility, these territories avoided the virus for a long time. However, when the coronavirus hit, the pandemic began to escalate rapidly, with high death rates, due to the inability of local health systems to cope.

(4) A relationship was revealed between the coronavirus pandemic and Russian regional and industrial policy, based on the development of rich natural resource deposits (oil, gas, gold, diamonds, etc.) in the northern territories on a rotational basis. And this affected not only underdeveloped national autonomies, but also fairly well-off northern federal subjects: the Sakha Republic (Yakutia) and the Khanty-Mansi and Yamalo-Nenets autonomous okrugs. In their shift camps, due to the overcrowding of shift workers' residences, concentrated centers of infection began to emerge quickly, brought in from the areas of their permanent residence. In these conditions, the large companies developing the fields took extraordinary measures to evacuate the sick on charter flights. Most likely, the tactics and policy of the rotational method, taking into account the risks noted, should be adjusted. A very likely trend to be prepared for will be de-urbanization and a decrease in the attractiveness of life in megacities. 


\section{CONCLUSIONS}

It is too early to draw final conclusions about the results of combating the coronavirus pandemic in the Russian Federation. 2021 will be decisive in this confrontation. However, already now, it is possible to formulate a number of conclusions and outline the lessons learned from the first and second waves of COVID-19.

(1) Some of Russia's successes in confronting the COVID-19 pandemic during its first wave (despite the negative factors and conditions noted at the beginning of the article) were determined by the solidarity of the central and regional authorities. To a large extent, this was facilitated by the strong presidential power vertical and dominance of the ruling party in the leadership of federal subjects and cities. As a result, it was possible to avoid confrontation between the federal center and regions, between political parties, between national autonomies and the center, and between religions. Russian society was quite loyal and understanding to the imposed restrictions; during the first wave and summer decline in the morbidity rate, there were hardly any mass protests on this matter (apart from several rallies in the Republic of Dagestan). ${ }^{17}$

This suggests a lesson for the future: in development of global threats, power and society, various branches of government, political parties, and business should consolidate and not come into conflict with each other.

(2) At a certain stage, the transfer of powers to combat the pandemic to federal subjects contributed to strengthening of federal principles in Russia, although in some cases, interstate and interbudgetary relations were semiformal or insufficient. Unfortunately, the opportunities for horizontal cooperation within the framework of intergovernmental relations and interregional integration were poorly used. In this context, a possible lesson for the future is the need to implement in Russia a balance and compromise between the "competitive federalism" and "cooperative federalism" that have developed in a number of federations throughout the world.

On the one hand, the fight against global threats like the coronavirus pandemic will require, as noted above, widespread solidarity based on the understanding that such a fight is a common and not a private affair. On the other hand, the inevitable development of the digital economy, network forms of remote work, telemedicine, etc., will lead both to an increase in the digital inequality of Russian regions and their even greater asymmetry, as well as to their competition for highly qualified personnel, new technologies, the introduction of personalized medicine, etc. Although

\footnotetext{
${ }^{17}$ Unfortunately, since September 2020, in a number of Russian regions, an unformed movement of "COVID dissidence" has begun to develop, similar to processes in many European countries.
}

one of the dominants of "wild" Russian federalism during the deep economic and political crisis of the 1990s (political loyalty of regional elites in exchange for federal resources) has generally receded into the past, it is necessary to eliminate the rudiments of this system, which occasionally appear under "manual control" type relationships.

(3) At the national level, the correct vector of combating the coronavirus pandemic was chosen (rapid closing of borders, use of the state's mobilization capabilities, etc.), but the speed of movement along this vector was insufficient. The available gold and foreign exchange reserves of the country and the National Wealth Fund made it possible to at least double support for the population and business affected by the pandemic. It is necessary to understand the need for a more decisive and timely use of the resource capabilities of the federal center to overcome crisis situations, in which resources will be directed not to support the banking system, state-owned companies, natural monopolies, and oligarchic groups, but the country's citizens.

(4) An important lesson is that the coronavirus crisis, like any other, consists not only of losses and threats, but also new chances and opportunities, and the overwhelming majority of them are realized in specific cities and regions. During the pandemic, $\mathrm{R} \& \mathrm{D}$ and production of vaccines against COVID-19, new drugs, and protective equipment accelerated significantly. The organization of work in a number of businesses radically changed when a significant part of employees began to work remotely. The development and implementation of new technologies in the digital economy has dramatically accelerated to control the situation with the spread of the pandemic. New trends have emerged in the development of charity and volunteerism. Regional scientific and innovation systems began to play an increasingly important role, and the experience of the Novosibirsk Scientific Center proves this. Much of these new capabilities and possibilities did not occur spontaneously but were initiated by regional and city governments. This has increased the competitive position of specific regions in the federal system of modern Russia.

(5) The special role of the quality of regional and municipal government as the most important components of Russian federalism was revealed. For example, in the fall, in some Russian regions, a crisis situation developed so that almost all beds for COVID patients were filled and urgent intervention by the federal center was required. That showed that the authorities of a number of federal subjects did not prepare the necessary reserves of local health care facilities in a timely manner in the summer months, as was done in other regions. Most likely, this will necessitate the creation or strengthening of administrative structures in regional governments specifically designed to manage 
crisis situations (with overall control and administration by governors).

(6) The coronavirus crisis has clearly demonstrated the interconnectedness of states and the cross-border nature of threats. It is quite obvious that pandemics do not acknowledge borders, and here the role of crossborder cooperation in the future is extremely important both in preventing and combating diseases, while it is necessary to use the latest achievements in science and technology and share them with neighboring states. So, a possible lesson for the future may be the necessity to create supranational structures specifically focused on jointly countering new global threats. This is particularly true for Siberian and Far East regions sharing long borders with China, Mongolia, Kazakhstan, etc.

(7) In 2020, federal Russia actually acted according to the economic and administrative "mobilization scenario." Historical experience shows that Russia copes with crisis situations much better when working with mobilization scenarios than in stationary and stable conditions of development. However, the implementation of such scenarios requires a difficult choice between democratic institutions of federalism and authoritarian decisions, which often directly or indirectly contradict legislation and human rights, and those of local communities and business. This is a very difficult choice, but it is important not to cross the moral line when police measures and control systems are inadequately applied to the actual epidemiological and social situation. ${ }^{18}$

(8) Obviously, after the end of the coronavirus pandemic, Russia will need to qualitatively improve the health care system at the federal and regional levels, considering the experience, mistakes, and lessons of 2020-2021. In all likelihood, a significant increase in investment in this industry will be required, both to create significant reserve capacity and in to ensure a rational combination of mass, high-tech, public, private, tele-, and personalized medicine. The formation of "crisis medicine" should absolutely encompass all federal subjects, not just megalopolises and major cities.

Perhaps the most important conclusion is that the Russian Federation, despite all the just reproaches regarding the inefficiency of its economy and administrative system, and its lag behind advanced states in

\footnotetext{
${ }^{18}$ It should be noted that in Russia, in the first wave of combating the pandemic, the authorities of federal subjects and cities often backed violators of prohibitive measures; penalties were not applied ubiquitously. Perhaps only in Moscow was a stricter regime applied, when about 90000 violators of the mandatory self-isolation regime were fined in six months. It yielded results, and in September-October, the number of violations in the capital decreased from 1000 to 100 cases per day. However, in all likelihood, the regional authorities of federal subjects will need, based on the experience of European and a number of Asian countries (primarily China), to take more stringent measures in the future with respect to violators.
}

science and technology, has actually proven its ability to fight global threats at its own expense and resources. The true heroes of combating COVID-19 are doctors, volunteers, and workers in other risk areas. However, all this did not happen automatically and required an extraordinary increase in the state's attention to critical areas on the main frontier of combating the pandemic (healthcare, biopharmaceutical, virological, and medical science; the pharmaceutical industry; civil engineering, etc.). One can criticize the scale of funds allocated to support these spheres, but nevertheless they were significantly larger than in previous years.

Therefore, the most important lesson should be realization that in the future such support should not be in the form of one-time actions in crisis situations (in line with the age-old principle, "the peasant will not cross himself before it begins to thunder"). The practice of such support needs to become permanent, growing and spreading to other spheres of the economy and society. First, a radical increase in funding for science and higher education is required. ${ }^{19}$ Only a sharp breakthrough in the knowledge economy can ensure Russia's independence against similar global threats in the future. The practice of proactive and effective public administration at all levels should be consolidated and strengthened: federal, regional, and local.

The events of 2020 showed that the existing overcentralization of executive power in Russia's federal system has most likely approached its limit and can hardly be strengthened further. Experience of decentralization in relations between the federal center and regions during the fight against the coronavirus pandemic can be further consolidated and expanded not only for crisis situations, but also for the stationary and stable development of Russian federalism and implementation of an effective and socially oriented state regional policy.

\section{FUNDING}

The article was prepared within the state task to the IEIE SB RAS (project "Regional and Municipal Strategic Plan-

\footnotetext{
${ }^{19}$ On the website of the State Scientific center of Virology and Biotechnology Vector (science city of Koltsovo, Novosibirsk Oblast) (http://www.vector.nsc.ru/vakansii/), which made a colossal contribution to the fight against the coronavirus and became one of the undisputed Russian leaders in this area,in December 2020, a vacancy was posted for the position of junior researcher with high qualifications and a salary of RUB 20000 or more (as determined by federal conditions). Correspondence between government priorities and the motivations and priorities of young scientists is unlikely. The tendency of liquidation of Russian scientific foundations, excommunication of the Russian Academy of Sciences from examining the activities of "elite" state scientific centers and universities, a course for creating socalled "scientific clusters" like Western scientific societies, etc., do not bode well either for the state's declared attention to Russian science.
} 
ning and Administration in Modernizing State Regional Policy and Developing the Digital Economy").

\section{CONFLICT OF INTEREST}

The authors declare no conflict of interest.

\section{REFERENCES}

Aganbegyan, A.G., Crisis as an opportunity for socioeconomic development, Materialy Moskovskogo akademicheskogo ekonomicheskogo foruma, 14 maya 2020 (Proc. Moscow Academic Economic Forum, May 14, 2020), Moscow, 2020a. https://www.ieie.su/assets/ files/news/2020/statya-aganbegyana.pdf. Accessed October 11, 2020.

Aganbegyan, A.G., Requirement of a new socioeconomic policy, Sredneruss. Vestn. Obshch. Nauk, 2020b, vol. 15, no. 3, pp. 5-15.

Hale, T., Phillips, T., Petherick, A., Kira, B., Angrist, N., Aymar, K., Webster, S., Majumdar, S., Hallas, L., Tatlow, H., and Cameron-Blake, E., Risk of Openness Index: When Do Government Responses Need to Be Increased Or Maintained? Oxford: Blavatnik Sch. Gov., 2020. https://www.bsg.ox.ac.uk/sites/default/files/ 2020-09/092020-Risk-of-Openness-Index-BSG-Research-Note.pdf. Accessed November 20, 2020.

Kalabikhina, I. and Panin, A., Spatial choreography of the coronavirus, Popul. Econ., 2020, vol. 4, no. 2, pp. 123152.

Komin, M. and Poltoratskaya, V., Responsibility instead of rights: has the pandemic led to the federalization of Russia? RBK, 2020. https://www.rbc.ru/opinions/politics/04/04/2020/5e87291b9a7947054c55500f. Accessed October 7, 2020.

Kuznetsova, O.V., Vulnerability of the structure of regional economies in crisis conditions, Federalizm, 2020, no. 2 (98), pp. 20-38.

Leksin, V., Federativnaya Rossiya i eyo regional'naya politika (Federative Russia and Its Regional Policy), Moscow: INFRA-M, 2008.
Obshchestvo i pandemiya: opyt i uroki bor'by s COVID-19v Rossii (Society and Pandemic: Experience and Lessons of Prevention of COVID-19 in Russia), Mau, V.A., Ed., Moscow, 2020.

Nigmatulin, R.I., Nigmatulin, B.I., Aganbegyan, A.G., Abramov, M.D., and Kashin, V.A., Pandemiya 2020: Ekonomicheskii krizis $v$ Rossii. Chto nado delat' (Pandemic 2020: Economic Crisis in Russia. What to Do), Moscow: GEOTAR-Media, 2020.

Pandemic COVID-19. The view of Russian social geographers: a series of articles, Sots. -Ekon. Geogr., Vestn. Assots. Ross. Geogr.-Obshchestvoved., 2020, no. 1 (9), pp. 124-158.

Pertsev, A., Viral federalism: How the epidemic revealed the structure of regional power in Russia, Carnegie Moscow Center, 2020. https://carnegie.ru/commentary/81480. Accessed August 6, 2020.

Seliverstov, V.E., Genesis of federalism, regional development and regional policy of post-Soviet Russia, in Federalism As Decision-Making: Changes in Structures, Procedures and Policies, Studies in Territorial and Cultural Diversity Governance, vol. 3, Palermo, F. and Alber, E., Eds., Leiden: Brill Nijhoff, 2015, pp. 148166.

Shchetinina, I.V., State restrictive measures in a pandemic and their socioeconomic consequences, EKO, 2020, no. 5, pp. 156-174.

Smyth, R., Sharafutdinova, G., Model, T., and Klein, A., The Russian power vertical and the COVID-19 challenge: the trajectories of regional responses, PONARS Eurasia, 2020, no. 646. https://www.ponarseurasia.org/memo/russianpower-vertical-covid-19-challenge-trajectories-regional. Accessed September 18, 2020.

Trunova, N. and Zemlyanskii, D., The consequences of the sudden "crisis" federalism in Russia, Forbes, 2020, May 28. https://www.forbes.ru/finansy-i-investicii/ 401625-k-chemu-privel-vnezapno-nastupivshiykrizisnyy-federalizm. Accessed August 12, 2020.

Zubarevich, N.V., Pandemic and regions: results of January-August 2020, Ekon. Razvit. Ross., 2020, vol. 27, no. 11, pp. $91-95$. 